Vol. 8 (1999): 493-513.

\author{
Review
}

\title{
Pathogen derived resistance to Potato virus Y: mechanisms and risks
}

\author{
Tuula Mäki-Valkama \\ Department of Plant Biology, PO Box 28, FIN-00014 University of Helsinki, Finland, \\ e-mail: tuula.maki-valkama@helsinki.fi
}

Jari P.T. Valkonen

Swedish University of Agricultural Sciences, Genetic Centre, PO Box 7080, S-750 07 Uppsala, Sweden

\begin{abstract}
Since the concept of pathogen derived resistance (PDR) was proposed in 1985, genetic transformation of plants to express virus-derived sequences has been used to engineer resistance to many viruses. This paper reviews PDR approaches to Potato virus $Y$ (PVY, type member of the genus Potyvi$r u s)$. PDR to viruses operates often through RNA-mediated resistance mechanisms that do not require protein expression. Studies on the RNA-mediated resistance have led to the discovery of posttranscriptional gene silencing (PTGS), a mechanism that controls gene expression in eukaryotic cells and provides natural protection against virus infections. Viruses, in turn, can suppress the PTGS with some of their proteins, such as the helper component-proteinase protein of PVY. Expression of PVY proteins in transgenic plants entails a risk for heterologous encapsidation or synergism with viruses that infect the PVY-resistant transgenic plant. These risks are avoided using RNA-mediated resistance, but a risk still exists for recombination between the transgene transcript and the RNA genome of the infecting virus, which may create a virus with altered properties. The harmful consequences can be limited to some extent by removing functional motifs from the viral sequence used as a transgene.
\end{abstract}

Key words: genetic transformation, Solanum tuberosum, transgenic plants, virus resistance

\section{Introduction}

The idea of producing virus resistant plants by transforming them with genes derived from viruses was first proposed by Sanford and Johnston (1985). They reasoned that pathogen-spe- cific resistance could be obtained on a general basis by engineering the host plant to express genetic material of the parasite. The authors coined the concept of parasite-derived resistance that has since then been referred to as pathogenderived resistance (PDR).

Since introducing the concept of PDR, many 
Mäki-Valkama, T. \& Valkonen, J.P.T. Transgenic resistance to PVY.

Table 1. Applications for field tests on virus resistant transgenic potatoes in Europe (May 1999*).

\begin{tabular}{lll}
\hline Country & No. of field tests & Target virus $^{1}$ \\
\hline Denmark & 1 & PVY \\
Finland & 1 & PVY \\
& 1 & PVX \\
France & 1 & PVY \\
Germany & 2 & PLRV \\
& 2 & PVY \\
& 1 & PVX \\
Netherlands & 1 & PLRV \\
& 1 & PVX \\
Spain & 1 & not mentioned \\
Sweden & 1 & PMTV \\
& 1 & TRV \\
United Kingdom & 4 & PVX \\
& 3 & PVY \\
& 1 & PLRV \\
\hline
\end{tabular}

${ }^{1}$ PVY, Potato virus Y (genus Potyvirus); PVX, Potato virus $X$ (genus Potexvirus);

PLRV, Potato leaf roll virus (genus Polerovirus); PMTV, Potato mop-top virus (genus Pomovirus); TRV, Tobacco rattle virus (genus Tobravirus)

* Submission of new applications and development of the status of the submitted applications can be followed at the Internet: http://www.oecd.org/ehs/service.htm, http:// biotech.jrc.it/gmo.htm, http://www.aphis.usda.gov/biotech/ index.html

viral sequences were transferred to plants by genetic transformation. They included genes encoding a coat protein (Powell-Abel et al. 1986), a replicase (Golemboski et al. 1990), a proteinase (Vardi et al. 1993), or a viral movement protein (Malyshenko et al. 1993, Lapidot et al. 1993). Also viral sequences and constructs not producing proteins were used (Haan et al. 1992, Lindbo and Dougherty 1992b, Vlugt et al. 1992). Furthermore, genomes of defective interfering viruses (Stanley et al. 1990, Kollar et al. 1993), satellite RNA sequences (Harrison et al. 1987, Gerlach et al. 1987), or complete genomes of mild strains of viruses (Yamaya et al. 1988) were used as transgenes. In all these studies, increased resistance to virus infection or suppression of symptoms was observed in transgenic plants. The successful use of so many different viral genes was taken as an indication that virtually any kind of a viral sequence could be used to create virus resistance in transgenic plants.

Nowadays PDR is widely used to engineer virus resistance in crop plants, but only few of the reported, successful applications have reached the market. A virus resistant squash variety was released in the USA in July 1994. It was at the same time the first transgenic crop approved by authorities for commercial use, and was followed by a virus resistant papaya variety in 1996. Virus resistant transgenic potato cultivars engineered with the coat protein gene of Potato virus $Y$ (PVY, genus Potyvirus) and the replicase gene of Potato leaf roll virus (PLRV, genus Polerovirus) were approved for commercial use in the USA in December 1998 and February 1999 , respectively. These potato cultivars were also engineered for resistance to the Colorado potato beetle. In Europe, 152 applications have been submitted (until May 1999) to obtain permits for field tests on transgenic potatoes, of which 22 applications include virus resistant transgenic potatoes (Table 1).

\section{Potato virus $Y$ and its signifi- cance as a plant pathogen}

Potato virus $Y$ (PVY) causes significant yield losses in many crops of family Solanaceae, including potato, tobacco, tomato and pepper, in all cultivation areas in the World (De Bokx and Huttinga 1981). Several factors, such as the PVY strain, host resistance, time of infection during plant growth, and environmental conditions affect the severity of the disease. In potato, PVY can reduce yields up to $80 \%$. Co-infection with other viruses such as Potato virus $X$ (PVX, genus Potexvirus) can increase symptom severity (Shukla et al. 1994). Isolates of PVY from potato are placed to the ordinary $\left(\mathrm{PVY}^{\mathrm{O}}\right)$, tobacco 
Vol. 8 (1999): 493-513.

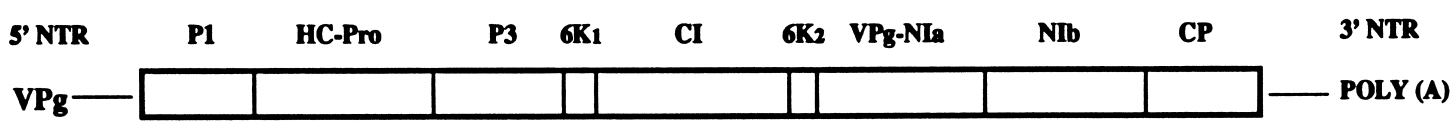

Fig. 1. The genome structure and the proteins produced from the single-stranded messenger-polarity RNA genome of Potato virus $Y$ (PVY). The genome contains short non-translated regions (NTR) flanking the single open reading frame, and a poly(A) tail at the 3'-end. The 5'-NTR enhances translation of a polyprotein subsequently processed by the viral proteinases (see below), whereas the 3'-NTR is important for virus replication (Nicolaisen et al. 1992, Simon-Buela et al. 1997). P1: the first protein is a proteinase that cleaves itself from the polyprotein (Verchot et al. 1991, Verchot and Carrington 1995). HC-Pro: multifunctional helper component-proteinase that cleaves itself from the polyprotein and is required for virus transmission by aphids, virus movement within the host plant, and suppression of the host gene silencing mechanism (Maia et al. 1996, Anandalakshimi et al. 1998, Andrejeva et al. 1999). P3: the third protein whose functions are unknown. CI: cylindrical inclusion protein (CI) is a helicase (Eagles et al. 1994) and a viral movement factor (Carrington et al. 1998), and it is flanked by two $6 \mathrm{~K}$ proteins (6K1 and 6K2) that are required during virus replication (Schaad et al. 1997). 6K2 is also involved in virus movement (Rajamäki and Valkonen 1999). NIa: nuclear inclusion protein a; a proteinase that cleaves most proteins from the polyprotein, including the viral protein genome linked (VPg) from the N-terminus of NIa. VPg is covalently bound to the 5'-end of the viral genome (Shahabuddin et al. 1988, Murphy et al. 1990, 1991). NIb: nuclear inclusion protein $b$ is the viral RNA-dependent RNA polymerase (replicase) (Riechmann et al. 1992). CP: the multifunctional coat protein encapsidates the viral genome to particles and is required for transmission by aphids and for virus movement within the plant (Mahajan et al. 1996, Rojas et al. 1997, Andrejeva et al. 1999).

veinal necrosis $\left(\mathrm{PVY}^{\mathrm{N}}\right)$, or stiple streak $\left(\mathrm{PVY}^{\mathrm{C}}\right)$ strain group, or strain group Z (PVYZ). Strain groups are based on the mosaic symptoms $\left(\mathrm{PVY}^{\mathrm{O}}, \mathrm{PVY}^{\mathrm{C}}\right.$ and $\mathrm{PVY}^{\mathrm{Z}}$ ) or necrotic symptoms $\left(\mathrm{PVY}^{\mathrm{N}}\right)$ induced in tobacco leaves, and the strain group specific hypersensitivity genes that $\mathrm{PVY} \mathrm{O}^{\mathrm{O}}$, $\mathrm{PVY}^{\mathrm{C}}$ and $\mathrm{PVY}^{\mathrm{Z}}$ elicit in potato cultivars (De Bokx and Huttinga 1981, Jones 1990, Valkonen et al. 1996). $\mathrm{PVY}^{\mathrm{N}}$ contains a subgroup of isolates, designated as PVY ${ }^{\mathrm{NTN}}$, that can induce necrosis on potato tubers (Beczner et al. 1984). In Finland, $\mathrm{PVY}^{\mathrm{N}}$ is more common than $\mathrm{PVY}^{\mathrm{O}}$ whereas elsewhere in Europe $\mathrm{PVY}^{\mathrm{O}}$ is more prevalent (Kurppa 1983, De Bokx and Want 1987).

PVY is the type member of genus Potyvirus (Pringle 1999) that contains a larger number of virus species infecting plants than any other virus genus. The genomic organization of potyviruses (reviewed by Riechmann et al. 1992) and the currently known main functions of potyviral proteins are presented in Figure 1.

Dispersal of PVY to and within susceptible crops occurs efficiently by aphid vectors that transmit PVY in a non-persistent manner. Therefore, control of PVY by killing the vectors with aphicides is not effective, and spraying with mineral oil provides only limited protection against transmission of PVY (Tiilikkala 1987). These problems exist in all crop species infected with PVY. Therefore, development of resistance to PVY in cultivars is of significant economic importance (Ross 1986, Watterson 1993).

In Finland, PVY is a significant pathogen in the potato crop (Kurppa 1983, Tapio et al. 1997). Most potato cultivars grown in Finland are susceptible to PVY or only partially protected against some strain groups of PVY (Valkonen and Mäkäräinen 1993, Valkonen and Palohuhta 1996). Breeding for resistance to PVY is carried out in Finland and elsewhere using natural resistance genes found in wild and cultivated potato species (Ross 1986, Valkonen 1994, Rokka 1998), which can be augmented by the use of DNA markers linked to the resistance genes (Hämäläinen et al. 1997, 1998, Brigneti et al. 1997, Sorri et al. 1999).

Combining resistance to the three most important potato viruses PVY, PVX and PLRV has proven difficult in breeding programs. Addition of a single trait, such as resistance to PVY, to a cultivar by genetic engineering is therefore an attractive option. 
Mäki-Valkama, T. \& Valkonen, J.P.T. Transgenic resistance to PVY.

\section{Pathogen derived resistance to PVY}

This review will concentrate on the studies where PVY has been the target virus for resistance engineering, irrespective of which host species has been transformed. PVY is an important pathogen in all major crop species of Solanaceae, and the transgenic approaches protecting one species against PVY are expected to work in the related species. However, this is not always the case and functionality needs to be tested in each case (Smith et al. 1994, 1995). Potato is well suited for experimental research using genetic engineering because transformation, regeneration and tissue culture techniques have been described for several potato varieties. However, most examples of PDR to PVY and, in particular, to other potyviruses have been described first in tobacco or other Nicotiana species, most used commonly as the experimental plants for genetic engineering.

The genes and sequences derived from PVY and transformed to plants do not yet cover all the genome of PVY (Fig. 1, Table 2). PVY and other potyviruses share similar genome structures and, therefore, Table 2 provides examples on additional genes and sequences from other potyviruses used successfully for resistance engineering.

In some cases, PDR has provided broad protection against several viruses. Table 3 provides examples of genes and sequences derived from other viruses and which have protected the transgenic plant against PVY.

\section{Coat protein gene mediated resistance}

The coat protein (CP) encoding region of PVY has been used to engineer resistance to PVY in potato (Kaniewski et al. 1990, Lawson et al. 1990, Farinelli et al. 1992, Wefels et al. 1993, Malnoë et al. 1994, Smith et al. 1995, Okamoto et al. 1996, Hefferon et al. 1997) and tobacco
(Vlugt et al. 1992, Farinelli and Malnoë 1993, Vlugt and Goldbach 1993, Smith et al. 1994, Young et al. 1995). The first study on potato used two CP genes, one derived from an ordinary strain of PVY $\left(\mathrm{PVY}^{\mathrm{O}}\right)$ and another one from PVX, that were transferred simultaneously into potato cv. Russet Burbank. One transgenic line showed resistance to both viruses, irrespective of whether inoculated separately or simultaneously, whether PVY was inoculated in sap or using the natural aphid vectors, or whether experiments were done under experimental conditions or in the field (Kaniewski et al. 1990, Lawson et al. 1990). The resistant line accumulated lower levels of transgenic PVY CP than other transgenic lines, which suggested that resistance was not based on the expressed recombinant $\mathrm{CP}$ but was probably functional at the RNA level. Resistance was specific to the viruses from which the transgenes were derived. No resistance to the unrelated viruses PLRV, Alfalfa mosaic virus (AlMV), Cucumber mosaic virus (CMV) or Tobacco mosaic virus (TMV) was observed. Resistance to other strains of PVY was not tested (Kaniewski et al. 1990, Lawson et al. 1990).

In two other studies $\mathrm{CP}$ genes were derived from isolates of another PVY strain group $\left(\mathrm{PVY}^{\mathrm{N}}\right)$ and transformed into potato cv. Bintje (Vlugt 1993, Malnoë et al. 1994). Plants transformed with the complete CP gene including 102 nt from the 3' non-translated region (3'-NTR) were not resistant to PVY (Vlugt 1993). In contrast, two transgenic lines (Bt6 and Bt10) expressing a sequence containing $285 \mathrm{nt}$ of the $\mathrm{NIb}$ gene, the entire CP gene, and 212 nt of the 3'NTR were resistant to PVY (Malnoë et al. 1994). An intriguing feature of the lines Bt6 and Bt10 was that the transgenic CP of PVYN was expressed at detectable levels only when the plants were infected with PVYO (Malnoë et al. 1994). Heteroencapsidation of the genomic RNA of $\mathrm{PVY}^{\mathrm{O}}$ by the transgenically expressed $\mathrm{PVY}^{\mathrm{N}} \mathrm{CP}$ was detected in the line Bt10 infected with $\mathrm{PVY}^{\mathrm{O}}$ (Farinelli et al. 1992).

Potato cv. Folva transformed with the CP gene from $\mathrm{PVY}^{\mathrm{N}}$ was resistant to one isolate of 
Vol. 8 (1999): 493-513.

Table 2. The genes and sequences from PVY and additional sequences from other potyviruses used to engineer virus resistance in transgenic plants (Solanaceae).

\begin{tabular}{|c|c|c|c|c|}
\hline Virus $^{1}$ & Sequence $^{2}$ & Orientation $^{3}$ & $\begin{array}{l}\text { Plant species } \\
\text { transformed }\end{array}$ & Reference \\
\hline \multirow[t]{13}{*}{ PVY } & \multirow[t]{2}{*}{$\mathrm{P} 1$} & $\mathrm{~S}$ & Potato & Pehu et al. 1995 \\
\hline & & AS & Potato & Mäki-Valkama et al. 1999 \\
\hline & \multirow[t]{4}{*}{ NIa } & $\mathrm{S}$ & Tobacco & Vardi et al.1993 \\
\hline & & $\mathrm{S}$ & Potato & Waterhouse et al. 1998 \\
\hline & & AS & Potato & Waterhouse et al. 1998 \\
\hline & & UN & Potato & Waterhouse et al. 1998 \\
\hline & \multirow[t]{2}{*}{$\mathrm{NIb}$} & $\mathrm{S}$ & Tobacco & Audy et al. 1994 \\
\hline & & $\mathrm{S}$ & Potato & Chachulska et al. 1998 \\
\hline & \multirow[t]{5}{*}{$\mathrm{CP}$} & $\mathrm{S}$ & Potato & Lawson et al. 1990, Kaniewski et al. 1990 \\
\hline & & $\mathrm{S}$ & Tobacco & Farinelli and Malnoë 1993 \\
\hline & & AS & Potato & Smith et al. 1995 \\
\hline & & UN & Potato & Smith et al. 1995 \\
\hline & & $\mathrm{UN}$ & Tobacco & van der Vlugt et al. 1993, Farinelli and Malnoë 1993 \\
\hline \multicolumn{5}{|c|}{ Additional sequences } \\
\hline TVMV & $\mathrm{P} 3$ & $\mathrm{~S}$ & Tobacco & Moreno et al. 1998 \\
\hline \multirow[t]{2}{*}{ TEV } & \multirow[t]{2}{*}{ VPg } & $\mathrm{S}$ & Tobacco & Swaney et al. 1995 \\
\hline & & $\mathrm{UN}$ & Tobacco & Swaney et al. 1995 \\
\hline
\end{tabular}

${ }^{1}$ PVY, Potato virus $Y$; TVMV, Tobacco vein mottling virus; TEV, Tobacco etch virus

${ }^{2} \mathrm{P} 1$, P1 proteinase; NIa, nuclear inclusion protein a; NIb, nuclear inclusion protein b; CP, coat protein; P3, $\mathrm{P} 3$ protein; VPg, viral protein genome linked

${ }^{3} \mathrm{~S}$, sense; AS, antisense; UN, untranslatable

Table 3. Heterologous protection against potato virus $\mathrm{Y}$ achieved using genes and sequences from other viruses.

\begin{tabular}{llll}
\hline & \multicolumn{2}{l}{ Viral } & \multicolumn{2}{l}{ Trans- } & \\
& sequence formed & \\
Virus (genus) & used $^{1}$ & species & Reference \\
\hline Soybean mosaic virus (Potyvirus) & CP & Tobacco & Stark and Beachy 1989 \\
Papaya ringspot virus (Potyvirus) & CP & Tobacco & Ling et al. 1991 \\
Watermelon mosaic virus II (Potyvirus) & CP & Tobacco & Namba et al. 1992 \\
Zucchini yellow mosaic virus (Potyvirus) & CP & Tobacco & Namba et al. 1992, Fang and Grumet \\
1993 & & & \\
Lettuce mosaic virus (Potyvirus) & CP & Tobacco & Dinant et al. 1993 \\
Plum pox virus (Potyvirus) & CP & Tobacco & Ravelonandro et al. 1993 \\
Tobacco vein mottling virus (Potyvirus) & CP & Tobacco & Maiti et al. 1993 \\
Potato leaf roll virus (Polerovirus) & MP & Potato & Tacke et al. 1996 \\
\hline
\end{tabular}

${ }^{1} \mathrm{CP}$, coat protein; MP, movement protein

$\mathrm{PVY}^{\mathrm{N}}$, two isolates of PVY ${ }^{\mathrm{NTN}}$ and two isolates of PVYO (Okamoto et al. 1996). Potato cvs. Russet Burbank and Russet Norkotah transformed with the translatable $\mathrm{CP}$ of $\mathrm{PVY}^{\mathrm{O}}$ were highly resistant to $\mathrm{PVY}^{\mathrm{O}}$ and $\mathrm{PVY}^{\mathrm{N}}$ (Smith et al. 1995). In both studies, the resistant plants accumulated low or undetectable levels of transgenic CP and the steady-state expression of the transgenic $\mathrm{CP}$ 


\section{AGRICULTURAL AND FOOD SCIENCE IN FINLAND}

Mäki-Valkama, T. \& Valkonen, J.P.T. Transgenic resistance to PVY.

mRNA was low (Smith et al. 1995, Okamoto et al. 1996).

CP-mediated resistance against both PVY strain groups $\mathrm{PVY} \mathrm{Y}^{\mathrm{O}}$ and $\mathrm{PV} \mathrm{Y}^{\mathrm{N}}$ was obtained in potato cvs. Russet Burbank, Shepody and Norchip using the $\mathrm{CP}$ gene of $\mathrm{PVY}^{\mathrm{O}}$ supplemented with a leader sequence from PVX (Hefferon et al. 1997). In contrast to the earlier mentioned studies, the level of protection against PVY in these plants positively correlated with the amounts of transgenic CP produced (Hefferon et al. 1997), which indicated that resistance was mediated via a protein-based mechanism.

\section{Resistance obtained using genes encoding non-structural proteins of PVY}

Tobacco plants that expressed the replicase gene (NIb) of PVYO showed a high level of resistance to PVYO (Audy et al. 1994). Also NIb genes deleted for one fifth of the 5'-end or one third of the 3 'end provided resistance to $\mathrm{PVY}^{\mathrm{O}}$. No transgenic line that expressed the NIb gene from which the GDD (Glycine, Aspartic acid, Aspartic acid) motif required for the function of viral polymerase was deleted was resistant to $\mathrm{PVY}$. Resistance was specific to $\mathrm{PVY}^{\mathrm{O}}$ and no protection against $\mathrm{PVY}^{\mathrm{N}}, \mathrm{CMV}$, Tobacco etch virus (TEV) or Pepper mottle virus (PepMoV) was observed (Audy et al. 1994).

A transgene containing the nuclear inclusion protein a (NIa) gene deleted for the $100 \mathrm{nt}$ from the 5'-end and supplemented with the first 251 nt from the NIb gene, and another construct containing the genes NIa, NIb and $\mathrm{CP}$, provided resistance to PVY in tobacco (Vardi et al. 1993).

In a recent study, tobacco lines were transformed with three different constructs of the PVY $^{\circ}$ NIa gene designed as Pro(S), Pro(AS) and Pro(S)-stop (Waterhouse et al. 1998). The Pro(S) and Pro(AS) lines contained the NIa gene in sense (protein-encoding) or antisense (non protein-encoding) orientation, respectively. The $\operatorname{Pro}(\mathrm{S})$-stop construct was similar to $\operatorname{Pro}(\mathrm{S})$, except that it contained a stop codon and a frameshift after the initiation codon, which prevented production of the NIa protein. Only few transgenic lines expressing each of these constructs were resistant to PVY. In contrast, simultaneous expression of both $\operatorname{Pro}(\mathrm{S})$ and $\operatorname{Pro}(\mathrm{AS})$ construct in the same line resulted in a high number of resistant lines (up to $54 \%$ of the regenerants). Also, many progeny lines from a cross between a susceptible Pro(S) line and a susceptible Pro(AS) were resistant to PVY. The progeny lines produced by selfing the $\operatorname{Pro}(\mathrm{S})$ or Pro(AS) lines, or by crossing different Pro(S) lines or Pro(AS) lines were susceptible (Waterhouse et al. 1998).

Several transgenic lines of the Finnish potato cv. Pito expressing a truncated P1 gene of $\mathrm{PVY}^{\mathrm{O}}$ in sense (Pehu et al. 1995) or antisense orientation (Mäki-Valkama et al. 1999) were resistant to $\mathrm{PVY}^{\mathrm{O}}$ following mechanical and graftinoculation. No symptoms developed and no detectable amounts of PVY accumulated in inoculated and the upper non-inoculated leaves. All lines were susceptible to PVYN ${ }^{\mathrm{N}}$ PVA and PVX.

\section{Heterologous protection against PVY using genes from other potyviruses}

Heterologous protection against PVY has been achieved in transgenic tobacco plants expressing $\mathrm{CP}$ genes from other potyviruses, of which examples are provided in Table 3. In fact, the first example of PDR to PVY was reported in a transgenic tobacco line transformed with the CP gene from Soybean mosaic virus (SbMV, genus Potyvirus) which does not infect tobacco plants naturally (Stark and Beachy 1989). The transgenic plants were also resistant to TEV. Resistance to PVY and TEV was expressed as a delayed development of symptoms that were attenuated. The most resistant transgenic line was not one of those showing the highest expression of transgenic SbMV CP. Protection to PVY and TEV was partially overcome by high amounts of virus inoculum (Stark and Beachy 1989). 
Vol. 8 (1999): 493-513.

There are also examples where sequences derived from unrelated viruses have provided resistance to PVY in transgenic plants. A defective movement protein gene (pr17) of PLRV containing a short $(2 \mathrm{kDa})$ hydrophilic extension at the N-terminus provided resistance to PLRV and PVYo in potato cv. Linda (Tacke et al. 1996).

\section{Resistance achieved by expressing viral RNA sequences that do not encode proteins}

The use of nontranslatable viral genes in sense orientation has been very successful for creating resistance to PVY (Vlugt et al. 1992, Farinelli and Malnoë 1993, Smith et al. 1994, Smith et al. 1995). One of the studies using an untranslatable CP gene of PVYN (Vlugt et al. 1992) was among the first examples where transgenic virus resistance was intentionally aimed to function at the RNA level (Haan et al. 1992, Lindbo and Dougherty 1992b, Vlugt et al. 1992). Since these original discoveries that resistance can operate at the RNA level, it has become evident that resistance is quite often functional at the RNA level and is not mediated by the protein. The untranslatable versions of PVY genes have mostly conferred virus strain-specific resistance to PVY, but non-translatable CP genes have provided resistance to more than one PVY strain group (Farinelli and Malnoë 1993, Smith et al. 1994, 1995). Resistance is usually correlated with a low steady-state level of transgenic messenger-RNA (mRNA) expression (Farinelli and Malnoë 1993, Smith et al. 1994, 1995).

Transformation with PVY genes in an antisense orientation has resulted in high levels of resistance to PVY only in few studies (Smith et al. 1995, Waterhouse et al. 1998, Mäki-Valkama et al. 1999). Delayed disease development and reduced virus titres have been observed (Farinelli and Malnoë 1993, Smith et al. 1994). Results can differ depending on the plant species transformed, as shown by the same antisense construct that was transformed into tobacco and potato and which protected only potato plants against PVY (Smith et al. 1994, 1995).

\section{Mechanism of PDR to viruses}

The mechanisms of PDR are not yet fully understood. It seems that there is no single mechanism that could explain all examples of PDR because some seem to require production of the recombinant protein whereas many require only the RNA transcript produced from the transgene.

\section{Protein-mediated resistance}

The first example of PDR to viruses was provided in plants that expressed the CP gene of TMV (Powell-Abel et al. 1986). Resistance was mediated by the recombinant $\mathrm{CP}$ and was based on the inhibition of virus disassembly (i.e. release of the viral nucleic acid from particles for initiation of translation) in the initially infected epidermal cells of tobacco plants (Register and Beachy 1988, Osbourn et al. 1989, ReimannPhilipp and Beachy 1993, Clark et al. 1995a, 1995b). The CP-mediated resistance in transgenic plants shares some similarities with the crossprotection phenomenon (McKinney 1929). Cross-protection prevents virus from infecting a plant that has already been infected with a related virus or virus strain. It may be due to a very early interference with virus infection, for example by the $\mathrm{CP}$ of the protecting virus inhibiting uncoating (dissassembly) of the infecting virus (Lu et al. 1998).

Dysfunctional viral movement proteins (MP) transformed to plants create "dominant-negative mutations" (Sanford and Johnston 1985, Herskowitz 1987). Plant viruses encode specific proteins that facilitate virus movement from cell to cell through plasmodesmata and over long distances through phloem. Several proteins of potyviruses are involved in virus transport (reviewed in Fig. 1). Virus transport is carried out 


\section{AGRICULTURAL AND FOOD SCIENCE IN FINLAND}

\section{Mäki-Valkama, T. \& Valkonen, J.P.T. Transgenic resistance to PVY.}

by the cellular transport mechanisms of the host (Lapidot et al. 1993). Hence, the MPs of different viruses interact with the same host transport mechanisms, which offers the possibility to create virus resistance by blocking such interactions through expression of non-functional MPs in transgenic plants (Malyshenko et al. 1993, Beck et al. 1994, Cooper et al. 1995, Tacke et al. 1996). The non-functional MP of PLRV was localized to the plasmodesmata of the sieve element-companion cell complex in transgenic potato plants and conferred resistance to PLRV, PVY and PVX (Tacke et al. 1996).

Many studies have used translatable CP genes or other genes from many viruses for transformation, but only in few instances has resistance expression been positively correlated with the $\mathrm{CP}$ expression. Only one example of protein-mediated resistance to PVY has been reported, as mentioned above (Hefferon et al. 1997). In most cases resistance seems to function at the RNA level.

\section{RNA mediated resistance}

Resistance mechanisms functional at an RNA level were revealed in transgenic plants expressing viral genes in an untranslatable form as mentioned above (Haan et al. 1992, Lindbo and Dougherty 1992b, Vlugt et al. 1992). Tobacco plants expressing an untranslatable CP gene of TEV showed recovery from the initially successful infection. The new developing leaves had milder or no symptoms, contained lower and ultimately non-detectable amounts of viral RNA and proteins, and could not be re-infected with TEV (Lindbo and Dougherty 1992b). Recovery from infection was later found to be characteristic of the RNA mediated resistance and gene silencing, as will be discussed later on.

The typical features of RNA mediated resistance include that resistance is specific to the virus or virus strain from which the transgene sequence is derived. Second, high level of resistance is obtained and further enhanced by an increased inoculum dose, while, in contrast, protein-mediated resistance is overcome by a high inoculum dose. Third, high levels of resistance are correlated with low levels of the steady-state transgenic mRNA expression. Furthermore, higher levels of resistance are usually associated with a higher transgene copy number and inverted copies of the transgene (Lindbo et al. 1993, Longstaff et al. 1993, Dougherty et al. 1994, Smith et al. 1994, Mueller et al. 1995, Swaney et al. 1995, Goodwin et al. 1996, Pang et al. 1996).

Some studies have attempted to determine the threshold sequence similarities between the transgene and the infecting virus required for activation of RNA mediated resistance (Pang et al. 1993, Longstaff et al. 1993, Mueller et al. 1995, Jones et al. 1998, Taliansky et al. 1998). Transgenic pea lines expressing the replicase (NIb) gene of Pea seed-borne mosaic virus (PSbMV, genus Potyvirus), isolate DPD1, showed recovery from infection following inoculation with isolate DPD1. Plants also recovered from infection with isolate L-1, in which the NIb gene shares $92 \%$ nucleotide sequence identity with the $\mathrm{NIb}$ gene of DPD1. Inoculation with isolate NY (89\% NIb nucleotide sequence identity with DPD1) resulted in recovery in one experiment but in a susceptible response in the second experiment (Jones et al. 1998). Hence, it was concluded that at least $89 \%$ sequence identity was required for activation of resistance.

Transgenic resistance to PVY has in some cases been effective only against the homologous virus isolate or strain group (e.g., Vlugt and Goldbach 1992, Audy et al. 1994, Malnoë et al. 1994, Mäki-Valkama et al. 1999). In other cases, resistance has acted against several strains of PVY (e.g., Smith et al. 1994, 1995, Young et al. 1995, Okamoto et al. 1996). These discrepancies can be at least partially explained in plants transformed with the CP genes, because the isolates from strain groups $\mathrm{PVY}^{\mathrm{O}}, \mathrm{PVY}^{\mathrm{N}}$ (and $\mathrm{PVY}^{\mathrm{NTN}}$ ) do not form completely distinct genetic clusters based on the CP sequences (Vlugt et al. 1993, Heuvel et al. 1994). Hence, no threshold sequence similarity value can be identified that includes all isolates of one strain group and excludes the others. 
Vol. 8 (1999): 493-513.

Many studies have not reported the sequences from the virus isolates used for inoculation, which hampers any attempt to explain the observed specificity of resistance by threshold sequence similarities. In potato cv. Pito transformed with a truncated P1 gene of PVYO (Pehu et al. 1995), resistance is functional only against isolates of $\mathrm{PVY}^{\mathrm{O}}$ (five isolates tested). This was unexpected because the isolates of $\mathrm{PVY}^{\mathrm{O}}$ and $\mathrm{PVY}^{\mathrm{N}}$ used for inoculations could not be distinguished based on their P1 gene sequences (MäkiValkama et al., unpublished). Therefore, other factors such as lower accumulation of PVYN in infected Pito plants and the consequently lower capacity to activate resistance may explain why $\mathrm{PVY}^{\mathrm{N}}$ is not affected by this resistance.

\section{Gene silencing}

Gene silencing occurs either transcriptionally through methylation of the promoter (Meyer et al. 1993, Neuhuber et al. 1994, Elmayan and Vaucheret 1996), or post-transcriptionally. The post-transcriptional gene silencing (PTGS) is more relevant regarding virus resistance (Baulcombe 1996b). It is by no means a phenomenon limited or specific to transgenic plants expressing resistance to PVY but is dealt with in this review because it provides a new and most likely broadly applicable concept for understanding the function of transgenic virus resistance and also natural, induced resistance to viruses in plants.

PTGS is a cytoplasmic event. It is characterized by a relatively high transcription rate and low or undetectable levels of mRNA and protein accumulation (de Carvalho et al. 1992, Dehio and Schell 1994, Ingelbrecht et al. 1994, Smith et al. 1994, Mueller et al. 1995, Elmayan and Vaucheret 1996, English et al. 1996, Goodwin et al. 1996). Also recovery from virus infection is correlated with reduction of the steadystate transgene mRNA levels, which is not due to reduction of the rate of transcription, shown by nuclear run-off studies (Lindbo et al. 1993, Dougherty et al. 1994, Mueller et al. 1995). It was first discovered as co-suppression of transgenes and the homologous endogenous genes that synthesize antocyanin pigments in flowers of petunia (Napoli et al. 1990, Krol et al. 1990).

\section{Targeted silencing of genes}

Quite elegant, directly visible examples of PTGS and its use for targeted silencing of selected host genes have been recently presented using plant viruses as gene vectors (Baulcombe 1999). Virus-induced gene silencing (VIGS) was first shown in nontransgenic Nicotiana benthamiana plants inoculated with a cytoplasmically replicating virus (TMV) that carried a phytoene desaturase (PDS) gene inserted into the viral genome (Kumagai et al. 1995). Expression of the plant's own PDS mRNA was reduced to an undetectable level following infection with the engineered TMV, resulting in severe chlorosis in the young systemically infected leaves where the virus replicated most efficiently. Chlorotic symptoms were due to low levels of PDS and the consequently blocked carotenoid synthesis, which makes the plant unprotected against photobleaching. Inoculation with the wild-type TMV caused no chlorosis.

In some cases PTGS does not only silence the host gene expression but is also targeted to the virus carrying the homologous gene insert (Ruiz et al. 1998). This latter phenomenon provides the mechanism how the virus-derived sequence inserted into the plant by transformation causes "silencing" of the subsequently infecting virus that contains a homologous sequence. Both homologous RNA sequences will then be degraded in the host cell by the same mechanism.

\section{Initiation of PTGS}

The core idea of the models explaining the mechanism of gene silencing is that an aberrant transcript of the transgene is recognized and short 


\section{AGRICULTURAL AND FOOD SCIENCE IN FINLAND}

\section{Mäki-Valkama, T. \& Valkonen, J.P.T. Transgenic resistance to PVY.}

complementary RNA molecules synthesized by specialized host-encoded RNA-dependent RNA polymerase (RdRp). The synthesized doublestranded RNA molecules activate a mechanism that degrades all RNA molecules homologous to the double-stranded sequence. Hence, any viral RNA sharing sufficient homology with the transgene sequence will be degraded in the cytoplasm (Dougherty and Parks 1995, Baulcombe 1996a, Baulcombe and English 1996, Wassenegger and Pélissier 1998). Evidence for RdRp genes in plants (tomato; Schiebel et al. 1998) and fungi (Neurospora crassa; Cogoni and Macino 1999) has recently been reported, and similar genes seem to exist in the animal kingdom (Cogoni and Macino 1999). These findings support the role of RdRp in PTGS.

The central role of double-stranded RNA in the initiation of PTGS is supported by several studies (Montgomery and Fire 1998, Waterhouse et al. 1998, Jorgensen et al. 1999, Selker 1999). Simultaneous expression of the NIa gene of PVY in sense and antisense orientation resulted in a higher percentage of transgenic tobacco lines with activated PTGS than the expression of the gene in only one orientation. These data can be explained by double stranded RNA molecules being readily born through pairing of the homologous sense and antisense transcripts in the first mentioned transgenic lines. Similarly, a cross between a sense and an antisense line carrying a single copy of the NIa gene resulted in PVY-resistant progeny, whereas the selfed parents resulted in PVY-susceptible progeny (Waterhouse et al. 1998). A higher transgene copy number (Sijen et al. 1996) and inverted transgene repeats (Stam et al. 1997, Selker 1999) also increase PTGS.

\section{Signals mediating systemic gene silencing}

Palaqui et al. (1997) showed that silencing was transmitted from a silenced rootstock to a nonsilenced scion grafted on the rootstock, indicated by a great reduction of the steady-state mRNA expression in the top scion expressing the same transgene as the rootstock. The messenger that mediates this systemic acquired silencing (SAS) was thought to be part of the transgene product, probably an aberrant poly(A)- RNA (Metzlaff et al. 1997, Palaqui et al. 1997). Currently, the signal is believed to contain douple-stranded RNA that is protected against degradation by a protein or by heteroduplex formation (Wassenegger and Pélissier 1999).

\section{Resetting PTGS}

PTGS is developmentally regulated and so-called meiotic resetting takes place. High levels of transgene transcription are observed immediately after germination of transgenic seeds that were harvested from plants where PTGS was active. Transgene expression then decreases during further growth of the seedlings, indicating that PTGS is reinitiated (de Carvalho et al. 1992, Dehio and Schell 1994, Dorlhac de Borne et al. 1994, Elmayan and Vaucheret 1996, Kunz et al. 1996, Pang et al. 1996, Tanzer et al. 1997). Therefore, small seedlings grown from seeds of a highly TEV-resistant, transgenic tobacco line are susceptible to TEV, whereas the older seedlings express high levels of resistance to TEV (Tanzer et al. 1997). Furthermore, silencing signals can pass through the dividing meristematic cells but silencing is not activated in such tissues (Voinnet et al. 1998).

Meiotic resetting may be due to a lack of transgene transcription in the apical meristem. Most studies have used the Cauliflower mosaic virus $35 \mathrm{~S}$ promoter that operates poorly in the apical meristem, for example in tobacco (Benfey et al. 1989, Benfey and Chua 1990). It is not known if PTGS is reset during dormancy of storage organs, such as tubers, or if resetting occurs, how quickly the re-initiation occurs after sprouting. It is also not documented how physiological changes, such as the differences in vitro and in vivo, may affect the ability of transgenic potatoes to maintain PTGS. The transcriptional silencing of the Plum pox virus derived NIb transgene was mitotically stable in Nicotiana bentha- 
Vol. 8 (1999): 493-513.

miana plants propagated in vitro (Guo et al. 1999).

\section{Minimal lengths of sequences activating PTGS}

Minimum lengths have been estimated for the transgene transcript and the introduced homologous RNA molecule required for activation of PTGS. The minimum length for the transgene capable of activating PTGS against Tomato spotted wilt virus was 236-387 bp (Pang et al. 1997). Expression of smaller viral gene segments (92$235 \mathrm{bp}$ ) also resulted in PTGS if these segments were combined with a non-homologous DNA sequence to increase the transgene size (Pang et al. 1997). A segment of only 60 nucleotides from the movement protein gene of Cowpea mosaic virus introduced by means of a PVX-based gene vector was sufficient to activate PTGS in transgenic plants that expressed the homologous, complete viral movement protein gene (Sijen et al. 1996).

\section{PTGS is a natural mechanism of virus resistance}

Discovery of PTGS in transgenic plants has prompted studies to resolve its original role in non-transgenic plants. Subsequently, PTGS was found to be associated with the natural recovery of plants from virus infection (Covey et al. 1997, Ratcliff et al. 1997, Al-Kaff et al. 1998). For example, recovery of Nicotiana clevelandii plants from infection with Tomato black ring virus (genus Nepovirus) provides an induced stage of resistance where the plants resist further inoculations with virus isolates that share certain sequence homology with the isolate that triggered PTGS and recovery (Ratcliff et al. 1997). According to the current knowledge, PTGS is found in different eukaryotic organisms where it degrades aberrant mRNA molecules, regulates host gene expression and also protects the cell against infection with viruses (Cogoni and Macino 1999, Selker 1999).

As recognition of quite small virus-specific sequences can be sufficient for activation of PTGS, as explained earlier, it becomes more understandable how certain natural, virus-induced resistance mechanisms could be based on PTGS (Ratcliff et al. 1997, Li et al. 1999, Valkonen and Watanabe 1999). Otherwise, it is difficult to see how activation of PTGS can happen in non-transgenic plants where large DNA fragments with high sequence similarity to plant viruses do not naturally exist.

\section{The ability of viruses to suppress PTGS}

Discovery of PTGS as a natural, conserved defense mechanism against viruses provided good reasons to suspect that viruses might have strategies to overcome it (Anandalakshmi et al. 1998, Brigneti et al. 1998, Kasschau and Carrington 1998). In fact, the ability to suppress PTGS may be crucial for the virus to be able to infect many if not all of its hosts. Indeed, evidence for the ability of viruses to suppress host gene silencing was recently provided. The HC-Pro of PVY and TEV, and the $2 \mathrm{~b}$ protein of CMV can suppress PTGS (Anandalakshmi et al. 1998, Brigneti et al. 1998, Kasschau and Carrington 1998). Expression of HC-Pro or $2 b$ from a heterologous virus genome (PVX gene vector) in transgenic plants recovered expression of the marker transgenes that had previously been silenced by PTGS. The gene vector (PVX) alone did not recover the transgene expression. Suppression of PTGS by PVY HC-Pro may also explain the previously described case of the transgenic potato line Bt10 (Malnoë et al. 1994). This line was transformed with the CP gene of $\mathrm{PVY}^{\mathrm{N}}$ but expressed detectable amounts of the recombinant $\mathrm{CP}$ only when infected with $\mathrm{PVY}{ }^{\mathrm{O}}$.

It seems that certain viral proteins have an ability to suppress PTGS in a general manner, independent from the gene or sequence that induced the PTGS, while PTGS is directed only against sequences that are highly homologous 
Mäki-Valkama, T. \& Valkonen, J.P.T. Transgenic resistance to PVY.

to the sequence that activated PTGS. How can then any transgenic plant transformed with genes from potyviruses, such as PVY, be protected against the homologous virus if these viruses carry a suppressor of PTGS? This is possible probably because PTGS is already activated prior to infection and degrades viral RNA before any significant amounts of viral proteins are translated from it (Lindbo and Dougherty 1992a, 1992b, Lindbo et al. 1993, Kasschau and Carrington 1998).

\section{Risks associated with the use of PDR to PVY}

Risks associated with the cultivation of transgenic plants can be divided into two categories, namely those related to the use of the transgenic plants as a crop in the agricultural environment, and those due to the specific trait introduced into the plant. The following will deal only with potatoes and engineered virus resistance.

\section{Risks associated with the cultivation of transgenic potatoes}

Potato (Solanum tuberosum L.) has been cultivated in Finland for over 200 years (Sauli 1941). Only two native, distantly related species $(S$. dulcamara L. and S. nigrum L.) of potato occur in Finland (Hämet-Ahti et al. 1998). They do not hybridize with potato under field conditions (Dale 1992, Kapteijns 1993). Therefore, gene transfer from transgenic potatoes to natural relatives is extremely unlikely in Finland and also many other potato cultivation areas (Dale 1992, Goy and Duesing 1996). The cultivated potato has not invaded and become established outside the potato fields in Finland or elsewhere in northern Europe during its long cultivation history, which indicates that transgenic potatoes won't "escape" to nature.
Potato cultivars may posses male sterility, premature flower abortion, incapability in pollen production, infertility, or self-fertility that reduce the chance of a cross between a transgenic and a nontransgenic potato cultivar in the field. Field experiments with transgenic potatoes indicate that the pollen dispersal from potatoes occurs only over limited distances, seldom exceeding 10 m (Skogsmyr 1994, Conner and Dale 1996). Therefore, the appropriate placement of transgenic and non-transgenic potato crops will prevent cross-pollination.

Movement of transgenes from a transgenic plant to plant-associated microbes has been discussed as a possible risk. Little experimental data support occurrence of this type of a horizontal gene transfer (HGT). Erwinia spp. are bacteria that infect and lyse potato tissue and can therefore come to contact with the plant nuclear DNA and the transgene. In a detailed study, the maximum frequency of HGT from transgenic potato tubers to Erwinia was estimated to be one infection of $7.5 \times 10^{14}$ infections occurring during a 2-hour incubation period (Schlüter et al. 1995). Thus, to obtain a single HGT event, 100 tons of potatoes should be inoculated with $10^{17}$ bacteria. Alternatively, considering the average yields of potato in Europe and the total number of any bacteria in soil, the calculated frequency corresponds to HGT to one bacterial cell in a potato field of 4.3 ha. Therefore, including HGT in a realistic risk assessment has been questioned (Schlüter et al. 1995).

\section{Risk associated with the use of engi- neered virus resistance}

The risks associated specifically with the trait of engineered virus resistance include heterologous encapsidation, synergism, and recombination (Tepher 1993, Valkonen 1998). The likelihood that any of these will occur depends on the viruses, host genotype (cultivar) and viral gene used for transformation, and which viruses and vectors occur in the geographic area during the 
Vol. 8 (1999): 493-513.

growing season. Similar factors also determine whether any actual harmful consequences from these events are expected. All these aspects must be taken into consideration in risk assessment.

Heterologous encapsidation, or transencapsidation, means that the viral genome of one virus is completely or partially encapsidated with the $\mathrm{CP}$ of another virus or virus isolate (Rochow 1970). It occurs primarily between related viruses and virus isolates in nature and can be expected to occur in transgenic plants expressing CP (Tepher 1993). Because CP is a determinant of vector transmissibility in many virus genera, heterologous encapsidation has practical significance if a non-transmissible virus is encapsidated with CP that provides the trait of vectortransmissibility. A non aphid-transmissible isolate of Zucchini yellow mosaic virus was transmitted by aphids after being encapsidated with the recombinant $\mathrm{CP}$ of an aphid-transmissible isolate of Plum pox virus in a transgenic plant (Lecoq et al. 1993, 1994). Heterologous encapsidation of PVYO RNA by the CP of PVYN produced from the transgene was shown in potato cv. Bintje (Farinelli et al. 1992). It is important to note that heterologous encapsidation has an effect only over one transmission event because infection in the new plant occurs with the encapsidated viral genome that encodes a CP lacking the ability to mediate aphid-transmissibility. Hence, no genetic change in the virus takes place.

Synergism is observed as a higher virus amount and/or more severe symptoms in the plant infected by two viruses, as compared to a plant infected with one of the two viruses. Many synergistic virus combinations are known. For example, co-infection with PVY and PVX results in increased titres of PVX (Vance et al. 1995), and co-infection with Sweet potato feathery mottle virus (SPFMV, genus Potyvirus) and Sweet potato chlorotic stunt virus (SPCSV, genus Crinivirus) results in greatly increased titres of SPFMV and very severe symptoms in sweet potato (Karyeija et al. 1998). Synergy can result from complementation of virus replication or movement and be associated with single viral genes. Complementation of cell-to-cell and long distance transport in plants occurs between unrelated viruses (Atabekov and Taliansky 1990). Therefore, expression of viral movement proteins, e.g., HC-Pro, cylindrical inclusion protein (CI), the viral genome-linked protein (VPg) or CP of PVY (Fig. 1), in transgenic plants may open the possibility for an unrelated virus to expand its host range to the transgenic species (Kaplan et al. 1995, Fenczik et al. 1995, Fujita et al. 1996). In addition to virus movement, the P1/HC-Pro region of PVY mediates synergism with PVX (Vance et al. 1995), and, as described above, is a suppressor of PTGS.

Production of virus proteins in plants and their consumption as food possesses no new risks because virus-infected plant products are commonly used, probably every day. Also, the amount of viral protein produced in the transgenic plant is many times less than the amounts in plants infected with the virus. Other above described risks could be avoided if the viral gene was modified to produce a non-functional protein, or no protein at all. It is therefore important that in most cases, resistance is indeed mediated at RNA level and production of the corresponding viral protein is not required for resistance.

Unfortunately, RNA mediated virus resistance also possesses certain risks, most notably the possibility for RNA recombination between the transcript of the transgene and the RNA genome of an infecting virus. Recombination would alter the genome of the virus and might consequently provide the virus with new properties, such as altered vector transmissibility or symptom induction, and might contribute to development of new viruses and virus strains ( $\mathrm{Si}$ mon and Bujarski 1994, Aaziz and Tepfer 1999, Reade et al. 1999, Rubio et al. 1999). Recombinants have been described among natural isolates from many plant virus genera (Simon and Bujarski 1994), including PVY and other potyviruses (Revers et al. 1996).

Transgene transcripts are produced virtually in all cells, which provides a high chance for recombination in the transgenic plant. Howev- 
Mäki-Valkama, T. \& Valkonen, J.P.T. Transgenic resistance to PVY.

er, the known examples of recombinant viruses born in transgenic plants (Lommel and Xiong 1991, Gal et al. 1992, Schoelz and Wintermantel 1993, Greene and Allison 1994, Borja et al. 1999) were described under a selection pressure much exceeding what occurs in the field. On the other hand, cultivation of the same transgenic cultivar in large areas increases the odds of a rare recombination event in an individual plant.

While realizing the theoretical risks, it is also important to realize that the resistance based on PTGS will affect the recombinant virus, too, in many cases. This is because the recombinant virus will contain a part from the transgene, the activated PTGS is specifically targeted to sequences homologous to the transgene, and sequences as short as 60 nucleotides can be targeted by PTGS (Sijen et al. 1996). The theoretical risks can be avoided or further minimized by the elimination of those nucleotides and sequences from the transgene that are known to be critical for a viral function (vector transmission, movement, replication, host specificity) (Greene and Allison 1996, Jacquet et al. 1998, Pang et al. 1997).

\section{Conclusions}

The studies reviewed in this paper show that efficient resistance to PVY can be obtained through the expression of $\mathrm{CP}$ and nonstructural viral genes in transgenic plants, including potato. The limitations of this approach has included the genetically narrow range of isolates and strains against which the transgene have provided protection, and the risks for heteroencapsidation, synergism and recombination with viruses that are able to infect the transgenic plant. Better understanding of the resistance mechanisms will allow the design of constructs for broader and more effective resistance. In the meanwhile, the use of untranslatable virus genes, antisense constructs and transgene sequences from which functional viral motifs have been deleted helps to reduce some of the risks. Durability of the resistance expression after several plant generations and the effects of environmental factors on resistance expression require further examination.

The use of transgenic PVY-resistant potatoes at an agricultural scale will ultimately depend on the public perception (Ruibal-Mendieta and Lints 1998). At the time being, the developments in Europe and the USA are quite contradictory. The former is becoming more restrictive and concerned about the use of transgenic crops and food while the latter is concerned about the restrictions to the marketable use of transgenic crops and investigates possibilities to make transgenic plants more accessible to agricultural use. One of the paradigms is that there is misbelief among the public concerning the risk assessment done on ecological and health consequences, because the assessment is done by the companies who aim to market and release the transgenic crop. This procedure is a requirement by law (e.g., in Finland: Geenitekniikkalaki 377/ 95) but it would certainly help if more independent risk assessment was also carried out by scientists financed by public sources at universities and other institutions.

Discovery of PTGS in transgenic plants has been of intrinsic scientific value in understanding natural virus resistance mechanisms in plants. This knowledge is likely to provide ideas and tools for creating new strategies for the control of plant viruses. In the future, transformation of cultivars with isolated, natural virus resistance genes can provide an alternative to the engineered pathogen-derived resistance. Due to the limitations in both approaches used alone, combination of the natural and engineered resistance mechanisms could provide the most durable resistance to viruses.

Acknowledgements. The authors thank the Academy of Finland (grants 27112 and 36256) and August Johannes ja Aino Tiuran Säätiö, Finland, as well as the Council for Forestry and Agricultural Research (SJFR, grant 32.0667/97), Carl Tryggers Stiftelse (grant \#98:330) and Stiftelsen för Strategisk Forskning, Sweden, for supporting the studies on resistance to PVY in potato. 
Vol. 8 (1999): 493-513.

\section{References}

Aaziz, R. \& Tepfer, M. 1999. Recombination in RNA viruses and in virus-resistant transgenic plants. Journal of General Virology 80: 1339-1346.

Al-Kaff, N.S., Covey, S.N., Kreike, M.M., Page, A.M., Pinder, R. \& Dale, P.J. 1998. Transcriptional and posttranscriptional plant gene silencing in response to a pathogen. Science 279: 2113-2115.

Anandalakshmi, R., Pruss, G.J., Ge, X., Marathe, R., Mallory, A.C., Smith, T.H. \& Vance, V.B. 1998. A viral suppressor of gene silencing in plants. Proceedings of the National Academy of Sciences USA 95: 1307913084.

Andrejeva, J., Puurand, Ü., Merits, A., Rabenstein, F., Järvekülg, L. \& Valkonen, J.P.T. 1999. Potyviral HCPro and CP proteins have coordinated functions in virus-host interactions, and the same $\mathrm{CP}$ motif affects virus transmission and accumulation. Journal of General Virology 80: 1133-1139.

Atabekov, J.G. \& Taliansky, M.E. 1990. Expression of a plant virus-coded transport function by different viral genomes. Advances in Virus Research 38: 201-248.

Audy, P., Palukaitis, P., Slack, S.A. \& Zaitlin, M. 1994. Replicase-mediated resistance to potato virus $Y$ in transgenic tobacco plants. Molecular Plant-Microbe Interactions 7, 1:15-22.

Baulcombe, D.C. 1996a. RNA as a target and an initiator of post-transcriptional gene silencing in transgenic plants. Plant Molecular Biology 32: 79-88.

- 1996b. Mechanism of pathogen-derived resistance to viruses in transgenic plants. The Plant Cell 8: 1833-1844.

- 1999. Fast forward genetics based on virus-induced gene silencing. Current Opinions in Plant Biology 2: 109-113.

- \& English, J.J. 1996. Ectopic pairing of homologous DNA and post-transcriptional gene silencing in transgenic plants. Current Opinion in Biotechnology 7: 173-180.

Beck, D.L., Dolleweerd, C.J. van, Lough, T.J., Balmori, E., Voot, D.M., Andersen, M.T., O'Brien, E.W. \& Forsters, L.S. 1994. Disruption of virus movement confers broad-spectrum resistance against systemic infection by plant viruses with a triple gene block. Proceedings of the National Academy of Sciences USA 91: 10310-10314.

Beczner, L., Horvath, J., Romhanyi, I. \& Förster, H. 1984. Studies on the etiology of tuber necrotic ringspot disease in potato. Potato Research 27: 339-352.

Benfey, P.N., Ren, L. \& Chua, N.-H. 1989. The CaMV 35S enhancer contains at least two domains which can confer different developmental and tissue-specific expression patterns. EMBO Journal 8: 21952202.

- \& Chua, N.-H. 1990. The cauliflower mosaic virus 35S promoter: combinatorial regulation of transcription in plants. Science 250: 959-966.

Borja, M., Rubio, T., Scholthof, H.B. \& Jackson, A.O. 1999. Restoration of wild-type virus by double recom- bination of tombusvirus mutants with a host trasgene. Molecular Plant-Microbe Interactions 12, 2: 153-162.

Brigneti, G., Garcia-Mas, J. \& Baulcombe, D.C. 1997. Molecular mapping of the potato virus $Y$ resistance gene $R y_{\text {sto }}$ in potato. Theoretical and Applied Genetics 94: 198-203.

- , Voinnet, O., Li, W.-X., Ji, L.-H., Ding, S.-W. \& Baulcombe, D.C. 1998. Viral pathogenicity determinants are suppressors of transgene silencing in Nicotiana benthamiana. EMBO Journal 17, 22: 6739-6746.

Carrington, J.C., Jensen, P.E. \& Schaad, M.C. 1998. Genetic evidence for an essential role for potyvirus $\mathrm{Cl}$ protein in cell-to-cell movement. Plant Journal 14: 393-400.

Chachulska, A.M., Flis, B., Chrzanowska, M., Milner, M., Góra-Sochacka, A., Robaglia, C. \& Zagórski, W. 1998. RNA -mediated potato virus $Y$ resistance in potato and tobacco. 7th International Congress of Plant Pathology. Edinburg, Scotland 9-16 August 1998. Abstract no. 5.3.6.

Clark, W.G., Fitchen, J.H. \& Beachy, R.N. 1995a. Studies of a coat protein -mediated resistance to TMV using mutant CP. I. The PM2 assembly defective mutant. Virology 208: 485-491.

- , Fitchen, J.H., Neijdat, A., Deom, C.M. \& Beachy, R.N. 1995b. Studies of a coat protein -mediated resistance to tobacco mosaic virus (TMV). II. Challenge by a mutant with altered virion surface does not overcome resistance conferred by TMV coat protein. Journal of General Virology 76: 2613-2617.

Cogoni,C. \& Macino, G. 1999. Gene silencing in Neurospora crassa requires a protein homologous to RNA-dependent RNA polymerase. Nature 399: 166169.

Conner, A.J. \& Dale, P.J. 1996. Reconsideration of pollen dispersal data from field trials of transgenic potatoes. Theoretical and Applied Genetics 92: 505-508.

Cooper, B., Lapidot, M., Heick, J.A., Dodds, J.A. \& Beachy, R.N. 1995. A defective movement protein of TMV in transgenic plants confers resistance to multiple viruses whereas the functional analog increases susceptibility. Virology 206: 307-313.

Covey, S.N., Al-Kaff, V.S., Lángara, A. \& Turner, D.S. 1997. Plants combat infection by gene silencing. Nature 385: 781-782.

Dale, P.J. 1992. Spread of engineered genes to wild relatives. Plant Physiology 100: 13-15.

de Carvalho, F., Gheysen, G., Kushnir, S., Montagu, M. van, Inzé, D. \& Castresana, C. 1992. Suppression of B-1,3 -glucanase transgene expression in homozygous plants. EMBO Journal 11: 2595-2602.

De Bokx, J.A. \& Want, J.P.H. van der 1987. Viruses of Potatoes and Seed-Potato Production. PUDOC, Wageningen. $259 \mathrm{p}$.

- \& Huttinga, H.1981. Potato virus Y. CMI/AAB Description of Plant Viruses no. 242.

Dehio, C. \& Schell, J. 1994. Identification of plant genetic loci involved in a post-transcriptional mechanism 
Mäki-Valkama, T. \& Valkonen, J.P.T. Transgenic resistance to PVY.

for meiotically reversible transgene silencing. Proceedings of the National Academy of Sciences USA 91: 5538-5542.

Dorlhac de Borne, F., Vincentz, M., Chupeau, Y. \& Vaucheret, H. 1994. Cosuppression of nitrate reductase host genes and transgenes in transgenic tobacco plants. Molecular and General Genetics 243: 613621.

Dougherty, W.G. \& Parks, T.D. 1995. Transgenes and gene suppression: telling us something new? Current Opinion in Cell Biology 7: 399-405.

- , Lindbo, J.A., Smith, H.A., Parks, T.D., Swaney, S. \& Proebsting, W.M. 1994. RNA-mediated virus resistance in transgenic plants: Exploitation of a cellular pathway possibly involved in RNA degradation. Molecular Plant-Microbe Interactions 7, 5: 544-552.

Eagles, R.M., Balmori-Melain, E., Beck, D.L., Gardner, R.C. \& Forster, R.L.S. 1994. Characterization of NTPase, RNA-binding and RNA-helicase activities of the cytoplasmic inclusion protein of tamarillo mosaic potyvirus. European Journal of Biochemistry 224: 677684.

Elmayan, T. \& Vaucheret, H. 1996. Expression of single copies of a strongly expressed $35 \mathrm{~S}$ transgene can be silenced post-transcriptionallly. Plant Journal 9, 6: 787-797.

English, J.J., Mueller, E. \& Baulcombe, D.C. 1996. Suppression of virus accumulation in transgenic plants exhibiting silencing of nuclear genes. Plant Cell 8: 179-188.

Fang, G. \& Grumet, R. 1993. Genetic engineering of potyvirus resistance using constructs derived from the zucchini yellow mosaic coat protein gene. Molecular Plant-Microbe Interactions 6, 3: 358-367.

Farinelli, L. \& Malnoë, P. 1993. Coat protein gene-mediated resistance to potato virus $Y$ in tobacco: Examination of the resistance mechanisms - Is the transgenic coat protein required for protection? Molecular Plant-Microbe Interactions 6, 3: 284-292.

- , Malnoë, P. \& Collet, G.F. 1992. Heterologous encapsidation of potato virus $Y$ strain $O\left(P V Y^{\circ}\right)$ with the transgenic coat protein of PVY strain $N\left(P V Y^{N}\right)$ in Solanum tuberosum cv. Bintje. Biotechnology 10: 1020-1025.

Fenczik, C.A., Padgett, H.S., Holt, C.A., Casper, S.J. \& Beachy, R.N. 1995. Mutational analysis of the movement protein of odontoglossum ringspot virus to identify a host-range determinant. Molecular Plant-Microbe Interactions 8: 666-673.

Fujita, Y., Mise, K., Okuno, T., Ahlquist, P. \& Furusawa, I. 1996. A single codon change in a conserved motif of a bromovirus movement protein gene confers compatibility with a new host. Virology 223: 283-291.

Gal, S., Pisan, B., Hohn, T., Grimsley, N. \& Hohn, B. 1992. Agroinfection of transgenic plants leads to viable cauliflower mosaic virus by intermolecular recombination. Virology 187: 525-533.

Gerlach, W.G., Lleewelyn, D. \& Haseloff, J. 1987. Construction of a plant disease resistance gene from the satellite RNA of tobacco ringspot virus. Nature 328: 802-805.

Golemboski, D.B., Lomonossoff, G.P. \& Zaitlin, M. 1990.
Plants transformed with a tobacco mosaic virus nonstructural gene sequence are resistant to the virus. Proceedings of the National Academy of Sciences USA 87: 6311-6315.

Goodwin, J., Chapman, K., Swaney, S., Parks, T.D., Wernsman, E.A. \& Dougherty, W.G. 1996. Genetic and biochemical dissection of transgenic RNA-mediated virus resistance. Plant Cell 8: 95-105.

Goy, P.A. \& Duesing, J.H. 1996. Assessing the environmental impact of gene transfer to wild relatives. Biotechnology 14: 39-40.

Greene, A.E. \& Allison, R.F. 1994. Recombination between viral RNA and transgenic plant transcripts. Science 263: 1423-1425.

- \& Allison, R.F. 1996. Deletions in the 3 untranslated region of cowpea chlorotic mottle virus transgene reduce recovery of recombinant viruses in transgenic plants. Virology 225: 231-234.

Guo, H.S., Lopez-Moya, J.J. \& Garcia, J.A. 1999. Mitotic stability of infection-induced resistance to plum pox potyvirus associated with transgene silencing and DNA methylation. Molecular Plant-Microbe Interactions 12: 103-111.

Haan, P. de, Gielen, J.J.L., Prins, M., Wijkamp, I.O., Schepen, A. van, Peters, D., Grinsven, M.Q.J.M. van \& Goldbach, R. 1992. Characterization of RNA-mediated resistance to tomato spotted wilt virus in transgenic tobacco plants. Biotechnology 10: 1133-1137.

Hämäläinen, J.H., Watanabe, K.N., Valkonen, J.P.T., Arihara, A., Plaisted, R.L., Pehu, E., Miller, L. \& Slack, S.A. 1997. Mapping and marker-assisted selection for a gene for extreme resistance to potato virus $\mathrm{Y}$. Theoretical and Applied Genetics 94: 192-197.

- , Sorri, V.A., Watanabe, K.N., Gebhardt, C. \& Valkonen, J.P.T. 1998. Molecular examination of a chromosome region that controls resistance to potato $Y$ and A potyviruses in potato. Theoretical and Applied Genetics 96: 1036-1043.

Hämet-Ahti, L., Suominen, J., Ulvinen, T. \& Uotila, P. (eds.). 1998. Retkeilykasvio. Yliopistopaino, Helsinki. $656 \mathrm{p}$.

Harrison, B.D., Mayo, M.A. \& Baulcombe, D.C. 1987. Virus resistance in transgenic plants that express cucumber mosaic virus satellite RNA. Nature 328 : 799-802.

Hefferon, K.L., Khalilian, H. \& Abouhaidar, M.G. 1997. Expression of the $P V Y^{\circ}$ coat protein $(C P)$ under the control of the PVX leader sequence: protection under greenhouse and field conditions against PVYO and PVYN infection in three potato cultivars. Theoretical and Applied Genetics 94: 287-292.

Herskowitz, I. 1987. Functional inactivation of genes by dominant negative mutations. Nature 329: 219-222.

Heuvel, J.F.J.M. van den, Vlugt, R.A.A.van der, Verbeek, M., Haan, P.T. de \& Huttinga, H. 1994. Characteristics of a resistance-breaking isolate of potato virus $Y$ causing potato tuber necrotic ringspot disease. European Journal of Plant Pathology 100: 347-356.

Ingelbrecht, I., Houdt, H. van, Montagu, M. van \& Depicker, A. 1994. Post-transcriptional silencing of reporter transgenes in tobacco correlates with DNA methylation. Proceedings of the National Academy 


\section{AGRICULTURAL AND FOOD SCIENCE IN FINLAND}

Vol. 8 (1999): 493-513.

of Sciences USA 91: 10502-10506.

Jacquet, C., Delecolle, B., Raccah, B., Lecoq, H., Dunez, J. \& Ravalonandro, M. 1998. Use of modified plum pox virus coat protein genes develop to limit heteroencapsidation - associated risks in transgenic plants. Journal of General Virology 79: 1509-1517.

Jones, A.L., Johansen, I.E., Bean, S.J., Bach, I. \& Maule, A.J. 1998. Specificity of the resistance to pea seedborne mosaic potyvirus in transgenic peas expressing the viral replicase (NIb) gene. Journal of General Virology 79: 3129-3137.

Jones, R.A.C. 1990. Strain group specific and virus specific hypersensitive reactions to infection with potyviruses in potato cultivars. Annals of Applied Biology 117: 93-105.

Jorgensen, R.A., Que, Q. \& Stam, M. 1999. Do unintended antisense transcripts contribute to sense cosuppression in plants? Trends in Genetics 15, 1: 11-12.

Kaniewski, W., Lawson, C., Sammons, B., Haley, L., Hart, J., Dealnnay, X. \& Tumer N.E. 1990. Field resistance of transgenic Russet Burbank potato to effects of infection by potato virus $\mathrm{X}$ and potato virus $\mathrm{Y}$. Biotechnology 8: 750-754.

Kaplan, I.B., Shintaku, M.H., Li, Q., Zhang, L., Marsh, L.E. \& Palukaitis, P. 1995. Complementation of virus movement in transgenic tobacco expressing the cucumber mosaic virus 3a gene. Virology 209: 188199.

Kapteijns, A.J.A.M. 1993. Risk assessment of genetically modified crops. potential of four arable crops to hybridize with the wild flora. Euphytica 66: 145-149.

Karyeija, R.F., Gibson, R.W. \& Valkonen, J.P.T. 1998. The significance of sweetpotato feathery mottle virus in subsistence sweet potato production in Africa. Plant Disease 82: 4-15.

Kasschau, K.D. \& Carrington, J.C. 1998. A counterdefensive strategy of plant viruses: Suppression of posttrancriptional gene silencing. Cell 95: 461-470.

Kollar, A., Dalmay, T. \& Burgyan, J. 1993. Defective interfering RNA-mediated resistance against cymbidium ringspot tombusvirus in transgenic plants. Virology 193: 313-318.

Krol, A.R. van der, Mur, L.A., Beld, M., Mol, J.N.M. \& Stuitje, A.R. 1990. Flavonoid genes in petunia: addition of a limited number of gene copies may lead to a suppression of gene expression. Plant Cell 2: 291299.

Kumagai, M.H., Donson, J., Della-Cioppa, G., Harvey, D., Hanley, K. \& Grill, L.K. 1995. Cytoplasmic inhibition of carotenoid biosynthesis with virus-derived RNA. Proceedings of the National Academy of Sciences USA 92: 1679-1683.

Kunz, C., Schöb, H., Stam, M., Kooter, J.M. \& Meins, F. 1996. Developmentally regulated silencing and reactivation of tobacco chitinase transgene expression. Plant Journal 10, 3: 437-450.

Kurppa, A. 1983. Potato viruses in Finland and their identification. Journal of the Scientific Agricultural Society of Finland 55: 183-300.

Lapidot, M., Gafny, R., Ding, B., Wolf, S., Lucas, W.J. \& Beachy, R.N. 1993. A dysfunctional movement protein of tobacco mosaic virus that partially modifies the plasmodesmata and limits virus spread in transgenic plants. Plant Journal 4, 6: 959-970.

Lawson, C., Kaniewski, W., Haley, L., Rozman, R., Newell, C., Sanders, P. \& Tumer, N.E. 1990. Engineering resistance to mixed virus infection in an commercial potato cultivar: Resistance to potato virus $X$ and potato virus $\mathrm{Y}$ in transgenic Russet Burbank. Biotechnology 8: 127-134.

Lecoq, H., Ravelonandro, M., Wiph-Scheibel, C., Monsion, M., Raccah, B. \& Dunez, J. 1993. Aphid transmission of a non-aphid-transmissible strain of zucchini yellow mosaic potyvirus from transgenic plants expressing the capsid protein of plum pox potyvirus. Molecular Plant-Microbe Interactions 6, 3: 403-406.

- , Ravelonandro, M., Wiph-Scheibel, C., Monsion, M., Raccah, B. \& Dunez, J. 1994. Significance of the heterologous encapsidation of zucchini yellow mosaic potyvirus in transgenic plants expressing plum pox potyvirus capsid protein. EPPO Bulletin 24 : $555-$ 559.

Li, H.-W., Lucy, A.P., Guo, H.-S., Li, W.-X., Ji, L.-H., Wong, S.-M. \& Ding, S.-W. 1999. Strong host resistance targeted against a viral suppressor of the plant gene silencing defence mechanism. EMBO Journal 18: 2683-2691.

Lindbo, J.A. \& Dougherty, W.G. 1992a. Pathogen-derived resistance to potyviruses: Immune and resistant phenotypes in transgenic tobacco expressing altered forms of a potyvirus coat protein nucleotide sequence. Molecular Plant-Microbe Interactions 5, 2: 144-153.

- \& Dougherty, W.G. 1992b. Untranslatable transcripts of the tobacco etch virus coat protein gene sequence can interfere with tobacco etch virus replication in transgenic plants and protoplasts. Virology 189: 725733.

- , Silva-Rosales, L., Proebsting, W.M. \& Dougherty, W. 1993. Induction of a highly specific antiviral state in transgenic plants: Implications for regulation of gene expression and virus resistance. Plant Cell 5: 17491759.

Ling, K., Namba, S., Gonsalves, C., Slightom, J.L. \& Gonsalves, D. 1991. Protection against detrimental effects of potyvirus infection in trasgenic tobacco plants expressing the papaya ringspot virus coat protein gene. Biotechnology 9: 752-758.

Lommel, S.A. \& Xiong, Z. 1991. Reconstitution of a functional red clover necrotic mosaic virus by recombinational rescue of the cell-to-cell movement gene expressed in a transgenic plant. Journal of Cell Biochemistry 15A: 151.

Longstaff, M., Brigneti, G., Boccard, F., Chapman, S. \& Baulcombe, D. 1993. Extreme resistance to potato virus $\mathrm{X}$ infection in plants expressing a modified component of the putative viral replicase. Embo Journal 12, 2: 379-386.

Lu, B., Stubbs, G. \& Culver, J.N. 1998. Coat protein interactions involved in tobacco mosaic tobamovirus cross-protection. Virology 248: 188-198.

Mahajan, S., Dolja, V.V. \& Carrington, J.C. 1996. Roles of the sequence encoding tobacco etch virus capsid protein in genome amplification: requirements for the 
Mäki-Valkama, T. \& Valkonen, J.P.T. Transgenic resistance to PVY.

translation process and a cis-acting element. Journal of Virology 70: 4370-4379.

Maia, I.G., Haenni, A.-L., \& Bernardi, F. 1996. Potyviral HC-Pro: a multifunctional protein. Journal of General Virology 77: 1335-1341.

Maiti, I.B., Murphy, J.F., Shaw, J.G. \& Hunt, A.G. 1993. Plants that express a potyvirus proteinase gene are resistant to virus infection. Proceedings of the $\mathrm{Na}$ tional Academy of Sciences USA 90: 6110-6114.

Mäki-Valkama, T., Pehu, T., Santala, A., Valkonen, J.P.T., Koivu, K., Lehto, K. \& Pehu, E. 1999. High level of resistance to potato virus $Y$ by expressing $P 1$ sequence in antisense orientation in transgenic potato. Molecular Breeding (in press).

Malnoë, P., Farinelli, L., Collet, G.F. \& Reust, W. 1994. Small-scale field tests with transgenic potato, cv. Bintje, to test resistance to primary and secondary infections with potato virus Y. Plant Molecular Biology 25: 963-975.

Malyshenko, S.I., Kondakova, O.A., Nazarova, K.V., Kaplan, I.B., Taliansky, M.E. \& Atabekov J.G. 1993. Reduction of tobacco mosaic virus accumulation in transgenic plants producing non-functional viral transport proteins. Journal of General Virology 74: 11491156.

McKinney, H.H. 1929. Mosaic diseases in the Canary Islands, West Africa and Gibraltar. Journal of Agricultural Research 39: 557-578.

Metzlaff, M., O’Dell, M., Cluster, P.D. \& Flavell, R.B. 1997. RNA-mediated RNA degradation and chalcone synthetase A silencing in Petunia. Cell 88: 845-854.

Meyer, P., Heidmann, J. \& Niedenhof, I. 1993. Differences in DNA-methylation are correlated with a paramutation phenomenon in trangenic petunia. Plant Journal 4: 89-100.

Montgomery, M.K. \& Fire, A. 1998. Double-stranded RNA as a mediator in sequence-specific genetic silencing and co-suppression. Trends in Genetics 14, 7: 255258.

Moreno, M., Bernal, J.J., Jiménez, I. \& Rodriquez-Cerezo, E. 1998. Resistance in plants transformed with the $\mathrm{P} 1$ or $\mathrm{P} 3$ gene of tobacco vein mottling virus. Virology 79: 2819-2827.

Mueller, E., Gilbert, J., Davenport, G., Brigneti, G. \& Baulcombe, D.C. 1995. Homology-dependent resistance: transgenic virus resistance in plants related to homology-dependent gene-silencing. Plant Journal 7 , 6: 1001-1013.

Murphy, J., Rhoads, R., Hunt, A.G. \& Shaw, J.G. 1990. The VPg of tobacco etch virus RNA is the $49 \mathrm{kDa}$ proteinase or the N-terminal $24 \mathrm{kDa}$ part of the proteinase. Virology 178: 285-288.

- , Rychlik, W., Rhoads, R.A., Hunt, A.G. \& Shaw J.G. 1991. A tyrosine residue in the small nuclear inclusion protein of tobacco vein mottling virus links the VPg to the viral RNA. Journal of Virology 65: 511513.

Namba, S., Ling, K., Gonsalves, C., Slightom, J.L. \& Gonsalves, D. 1992. Protection of transgenic plants expressing the coat protein gene of watermelon mosaic virus II or zucchini yellow mosaic virus against six potyviruses. Phytopathology 82: 940-946.
Napoli, C., Lemieux, C. \& Jorgensen, R. 1990. Introduction of a chimeric chalcone synthase gene into Petunia results in reversible co-suppression of homologous genes in trans. Plant Cell 2: 279-289.

Neuhuber, F., Park, Y.-D., Matzke, A.J.M. \& Matzke, M.A. 1994. Susceptibility of transgene loci to homologydependent gene silencing. Molecular and General Genetics 244: 230-241.

Nicolaisen, M., Johansen, E., Poulsen, G.B. \& Bokhardt, B. 1992. The 5' untranslated region from pea seedborne mosaic potyvirus RNA as a translational enhancer in pea and tobacco protoplasts. FEBS Letters 303: 169-172.

Okamoto, D., Nielsen, S.V.S., Albrechtsen, M. \& Borkhardt, B. 1996. General resistance against potato virus $Y$ introduced into a commercial potato cultivar by genetic transformation with $\mathrm{PVY}^{\mathrm{N}}$ coat protein. Potato Research 39: 271-282.

Osbourn, J.K., Watts, J.W., Beachy, R.N. \& Wilson, T.M.A. 1989. Evidence that nucleocapside disassembly and a later step in virus replication are inhibited in transgenic tobacco protoplasts expressing TMV coat protein. Virology 172: 370-373.

Palaqui, J.C., Elmayan, T., Pollien, J.-M. \& Vaucheret, H. 1997. Systemic acquired silencing: transgenespecific post-transcriptional silencing is transmitted by grafting from silenced stocks to non-sielenced scions. EMBO Journal 16, 15: 4738-4745.

Pang, S.-Z., Slightom, J.L. \& Gonsalves, D. 1993. Different meshanisms protect transgenic tobacco against tomato spotted wilt and impatiens necrotic spot Tospoviruses. Biotechnology 11: 819-824.

- , Jan, F.-J., Carney, K., Stout, J., Tricoli, D.M., Quemada, H.D. \& Gonsalves, D. 1996. Post-transcriptional transgene silencing and consequent tospovirus resistance in transgenic lettuce are affected by transgene dosage and plant development. Plant Journal 9, 6: 899-909.

- , Jan, F.-J. \& Gonsalves, D. 1997. Nontarget DNA sequences reduce the transgene length necessary for RNA-mediated tospovirus resistance in transgenic plants. Proceedings of the National Academy of Sciences USA 94: 8261-8266.

Pehu, T.M., Mäki-Valkama, T.K., Valkonen, J.P.T., Koivu, K.T., Lehto, K.M. \& Pehu, E.P. 1995. Potato plants transformed with a potato virus $\mathrm{Y} P 1$ gene sequence are resistant to $\mathrm{PVY}$. American Potato Journal 72: 523-532.

Powell-Abel, P., Nelson, R.S., De, B., Hoffmann, N., Rogers, S.G., Fraley, R.T. \& Beachy, R.N. 1986. Delay of disease development in transgenic plants that express the tobacco mosaic virus coat protein gene. Science 232: 738-743.

Pringle, C.R. 1999. Virus taxonomy - 1999. Archives of Virology 144: 421-429.

Rajamäki, M.-L. \& Valkonen, J.P.T. 1999. The 6K2 protein and VPg of Potato virus A are avirulence determinants associated with lack of systemic infection in Nicandra physaloides. Molecular Plant-Microbe Interactions 12: 1074-1081.

Ratcliff, F., Harrison, B.D. \& Baulcombe, D.C. 1997. A similarity between viral defence and gene silencing 


\section{AGRICULTURAL AND FOOD SCIENCE IN FINLAND}

Vol. 8 (1999): 493-513.

in plants. Science 276: 1558-1560.

Ravelonandro, M., Monsion, M., Delpos, R. \& Dunez J. 1993. Variable resistance to plum pox virus and potato virus $Y$ infection in transgenic Nicotiana plants expressing plum pox virus coat protein. Plant Science 91: 157-169.

Reade, R., Wu, Z. \& Rochon, D. 1999. Both RNA rearrangement and point mutation contribute to repair of defective chimeric viral genomes to form functional hybrid viruses in plants. Virology 258: 217-231.

Register, J.C. \& Beachy, R.N. 1988. Resistance to TMV in transgenic plants results from interference with an early event in infection. Virology 166: 524-532.

Reimann-Philipp, U. \& Beachy, R.N. 1993. Coat protein mediated resistance in transgenic tobacco expressing the tobacco mosaic virus coat protein from tissue-specific promoters. Molecular Plant-Microbe Interactions 6: 323-330.

Revers, F., Le Gall, O., Candresse, T., Le Romancer, M. \& Dunez, J. 1996. Frequent occurrence of recombinant potyvirus isolates. Journal of General Virology 77: 1953-1965.

Riechmann, J.L., Laín, S. \& Garcia, J.A. 1992. Highlights and prospects of potyvirus molecular biology. Journal of General Virology 73: 1-16.

Rochow, W.F. 1970. Barley yellow dwarf virus: Phenotypic mixing and vector specificity. Science 167: 875878.

Rojas, M.R., Zerbini, F.M., Allison, R.F., Gilbertson, R.L. \& Lucas, W.J. 1997. Capsid protein and helper component-proteinase function as potyvirus cell-to-cell movement proteins. Virology 237: 283-295.

Rokka, V.-M. 1998. Androgenic haploidization and interspecific and intraspecific somatic hybridization in potato germplasm development. PhD thesis. Department of Plant Production, University of Helsinki. $62 \mathrm{p}$.

Ross, H. 1986. Potato breeding - problems and perspectives. Journal of Plant Breeding. Supplement 13. $132 \mathrm{p}$.

Rubio, T., Borja, M., Scholthof, H.B. \& Jackson, A.O. 1999. Recombination with host transgenes and effects on virus evolution: an overview and opinion. Molecular Plant-Microbe Interactions 12, 2: 87-92.

Ruibal-Mendieta, N.L. \& Lints, F.A. 1998. Novel and transgenic food crops: overview of scientific versus public perception. Transgenic Research 7: 379-386.

Ruiz, M.T., Voinnet, O. \& Baulcombe, D.C. 1998. Initiation and maintenance of virus-induced gene silencing. Plant Cell 10: 937-946.

Sanford, J.C. \& Johnston, S.A. 1985. The consept of parasite-derived resistance: deriving resistance genes from parasite's own genome. Journal of Theoretical Biology 113: 395-405.

Sauli, J.O. 1941. Peruna. Yhteiskirjapaino. Helsinki. $126 \mathrm{p}$.

Schaad, M.C., Jensen, P.E. \& Carrington, J.C. 1997. Formation of plant RNA virus replication complexes on membranes: role of an endoplasmic reticulum-targeted viral protein. EMBO Journal 16: 4049-4059.

Schiebel, W., Pelissier, T., Riedel, L., Thalmeir, S., Schiebel, R., Kempe, D., Lottspeich, F., Sänger, H.L.
\& Wassenegger, M.1998. Isolation of an RNA-directed RNA polymerase-specific cDNA clone from tomato. Plant Cell 10: 2087-2101.

Schlüter, K., Fütterer, J. \& Potrykus, I. 1995. "Horizontal" gene transfer from a transgenic potato line to a bacterial pathogen (Erwinia chrysanthemi) occurs - if at all - at an extremely low freaquency. Biotechnology 13: 1094-1098.

Schoelz, J.E. \& Wintermantel, W.M. 1993. Expansion of viral host range through complementation and recombination in transgenic plants. Plant Cell 5: 1669-1679.

Selker, E.U. 1999. Gene silencing: repeats that count. Cell 97: 157-160.

Shahabuddin, M., Shaw, J.G. \& Rhoads, R.E. 1988. Mapping of the tobacco vein mottling virus VPg cistron. Virology 163: 635-637.

Shukla, D.D., Colin, W.W. \& Brunt, A.A. 1994. The Potyviridae. University Press, Cambridge, United Kindom, $516 \mathrm{p}$.

Sijen, T., Wellink, J., Hiriart, J.-B. \& Kammen, A. van 1996. RNA-mediated virus resistance: Role of repeated transgenes and delineation of targeted regions. Plant Cell 8: 2277-2294.

Simon, A.E. \& Bujarski, J.J. 1994. RNA-RNA recombination and evolution in virus-infected plants. Annual Review in Phytopathology 32: 337-362.

Simón-Buela, L., Guo, H.S. \& García, J.A. (1997a). Long sequences in the 5' noncoding region of plum pox virus are not necessary for viral infectivity but contribute to viral competitiveness and pathogenesis. Virology 233: 157-162.

Skogsmyr, I. 1994. Gene dispersal from transgenic potatoes to con-specifics: a field trial. Theoretical and Applied Genetics 88: 770-774.

Smith, H.A., Swaney, S.L., Parks, T.D., Wernsman, E.A. \& Dougherty, W.G. 1994. Transgenic plant virus resistance mediated by untranslatable sense RNAs: Expression, regulation, and fate of nonessential RNAs. Plant Cell 6: 1441-1453.

- , Powers, H., Swaney, S., Brown, C. \& Dougherty, W.G. 1995. Transgenic potato virus $Y$ resistance in potato: Evidence for an RNA-mediated cellular response. Phytopathology 85: 864-870.

Sorri, V.A., Watanabe, K.N. \& Valkonen, J.P.T. 1999. Predicted kinase 3 a motif of a resistance gene analogue as a unique marker for potyvirus resistance. Theoretical and Applied Genetics 99: 164-170.

Stam, M., de Bruin, R., Kenter, S., Hoorn, R.A.L. van der, Blokland, R. van, Mol, J.N.M. \& Kooter, J.M. 1997. Post-transcriptional silencing of chalcone synthase in Petunia by inverted repeats. Plant Journal 12, 1: 63-82.

Stanley, J., Frischmuth, T. \& Ellwood, S. 1990. Defective viral DNA ameliorates symptoms of geminivirus infection in transgenic plants. Proceedings of the $\mathrm{Na}$ tional Academy of Sciences USA 87: 6291-6295.

Stark, D. M. \& Beachy, R.N. 1989. Protection against potyvirus infection in transgenic plants: Evidence for broad spectrum resistance. Biotechnology 7: 12571262.

Swaney, S., Powers, H., Goodwin, J., Silva-Rosales, L \& Dougherty, W.G. 1995. RNA-mediated resistance with 
Mäki-Valkama, T. \& Valkonen, J.P.T. Transgenic resistance to PVY.

nonstructural genes from the tobacco etch virus genome. Molecular Plant-Microbe Interactions 8, 6: 1004-1011.

Tacke, E., Salamini, F. \& Rohde, W. 1996. Genetic engineering of potato for broad-spectrum protection against virus infection. Nature Biotechnology 14: 1597-1601.

Taliansky, M.E., Ryabov, E.V. \& Robinson, D.J. 1998. Two distinct mechanismis of transgenic resistance mediated by groundnut rosette virus satellite RNA sequences. Molecular Plant-Microbe Interactions 11, 5: 367-374.

Tanzer, M.M., Thompson, W.F., Law, M.D., Wernsman, E.A. \& Uknes, S. 1997. Characterization of post-transcriptionally suppressed transgene expression that confers resistance to tobacco etch virus infection in tobacco. Plant Cell 9: 1411-1423.

Tapio, E., Bremer, K. \& Valkonen, J.P.T. 1997. Viruses and their significance on agricultural and horticultural crops in Finland. Agricultural and Food Science in Finland 6: 323-336.

Tepher, M. 1993. Viral genes and transgenic plants. Biotechnology 11: 1125-1132.

Tiilikkala, K. 1987. Perunan Y -viroosin torjunta mineraaliöljyllä. M.S. Thesis, Department of Plant Pathology, University of Helsinki. 22 p. (In Finnish).

Valkonen, J.P.T. 1994. Natural genes and mechanisms of resistance to viruses in cultivated and wild potato species (Solanum spp.). Plant Breeding 112: 1-16.

- 1998. Virus disease control in plants using natural and engineered resistance, and some considerations regarding biosafety. In: Current Issues in International Rural Development No. 17/18. SLU/Sida, Sweden. p. 51-55.

- \& Mäkäräinen, E. 1993. Symptom expression and accumulation of potato virus Y (PVY-O) and potato leaf roll virus in thirteen potato cultivars. Agricultural Science in Finland 2: 33-40.

- \& Palohuhta, J.P. 1996. Resistance to potato virus A and potato virus $\mathrm{Y}$ in potato cultivars grown in Finland. Agricultural and Food Science in Finland 5: 5762.

- \& Watanabe, K.N. 1999. Autonomous cell death, temperature-sensitivity and the genetic control associated with resistance to cucumber mosaic virus (CMV) in diploid potatoes (Solanum spp.). Theoretical and Applied Genetics 99: 996-1005.

- , Jones, R.A.C., Slack, S.A. \& Watanabe, K.N. 1996. Resistance specificities to viruses in potato: standardization of nomenclature. Plant Breeding 115: 433438.

Vance, V.B., Berger, P.H., Carrington, J.C., Hunt, A.G. \& Shi, X.M. 1995. 5' proximal potyviral sequences mediate potato virus $\mathrm{X} /$ potyviral synergistic disease in transgenic tobacco. Virology 206: 583-590.

Vardi, E., Sela, I., Edelbaum, O., Livneh, O., Kuznetsova, L. \& Stram, Y. 1993. Plants transformed with a cistron of a potato virus $\mathrm{Y}$ protease (NIa) are resistant to virus infection. Proceedings of the National
Academy of Sciences USA 90: 7513-7517.

Verchot, J. \& Carrington, J.C. 1995. Evidence that the potyvirus $\mathrm{P} 1$ proteinase functions in trans as an accessory factor for genome amplification. Journal of Virology 69: 3668-3674.

- , Koonin, E.V. \& Carrington J.C. 1991. The 35-kDa protein from the $\mathrm{N}$-terminus of the potyviral polyprotein functions as a third virus-encoded proteinase. Virology 185: 527-535.

Vlugt, R. van der 1993. Engineered resistance against potato virus Y. Ph.D. Thesis. Agricultural University, Wageningen, the Netherlands. $111 \mathrm{p}$.

- \& Goldbach, R.W. 1993. Tobacco plants transformed with the potato virus $Y^{N}$ coat protein gene are protected against PVY isolates and against aphid-mediated infection. Transgenic Research 2: 109-114.

- , Ruiter, R.K. \& Goldbach, R. 1992. Evidence for sense RNA-mediated protection to PVYN in tobacco plants transformed with the viral coat protein cistron. Plant Molecular Biology 20: 631-639.

- , Leunissen, J. \& Goldbach, R. 1993. Taxonomic relationships between distinct potato virus $Y$ isolates based on detailed comparison of the viral coat proteins and 3'-nontranslated regions. Archives of Virology 131: 361-375.

Voinnet, O., Vain, P., Angell, S. \& Baulcombe, D.C. 1998. Systemic spread of sequence-specific transgene RNA degradation in plants is initiated by localized introduction of ectopic promotorless DNA. Cell 95: 177-187.

Wassenegger, M. \& Pélissier, T. 1998. A model for RNA mediated gene silencing in higher plants. Plant Molecular Biology 37: 349-362.

- \& Pélissier, T. 1999. Signalling in gene silencing. Trends in Plant Science 4: 207-209.

Waterhouse, P.M., Graham, M.W. \& Wang, M.-B. 1998. Virus resistance and gene silencing in plants can be induced by simultaneous expression of sense and antisense RNA. Proceedings of the National Academy of Sciences USA 95: 13959-13964.

Watterson, J.C. 1993. Development and breeding for resistance to pepper and tomato viruses. In: Kyle, M.M. (ed.). Resistance to Viral Diseases of Vegetables. Timber Press, Oregon, USA. p. 80-101.

Wefels, E., Salamini, F. \& Rohde, W. 1993. Modification at the $\mathrm{N}$-terminus of the potato virus $\mathrm{Y}$ capsid protein $\mathrm{CP}$ does not interfere with CP-mediated virus resistance in transgenic potato (Solanum tuberosum L.). Journal of Genetics and Breeding 47: 89-93.

Yamaya, J., Yoshioka, M., Meshi, T., Okada, Y. \& Ohno, T. 1988. Cross protection in transgenic tobacco plants expressing a mild strain of tobacco mosaic virus. Molecular and General Genetics 215: 173-175.

Young, S.J.B., Woloshuk, S.L., Parry, D.C., Hellmann, G.M., Wernsman, E.A., Lommel, S.A. \& Weissinger, A.K. 1995. Transgenic Burley and Flue-cured tobacco with resistance to four necrotic isolates of potato virus Y. Phytopathology 85: 1493-1499. 
Vol. 8 (1999): 493-513.

\title{
SELOSTUS
}

\section{Patogeenivälitteinen, siirtogeeninen kestävyys perunan Y-virusta vastaan: mekanismit ja riskit}

\author{
Tuula Mäki-Valkama ja Jari P.T. Valkonen \\ Helsingin yliopisto ja Ruotsin maatalouskorkeakoulu
}

Perunan Y-virus (PVY) aiheuttaa maailmanlaajuisesti merkittäviä satotappioita Solanaceae-heimon viljelykasveissa kuten perunassa, tomaatissa, paprikassa ja tupakassa. Suomessa PVY on yksi tärkeimmistä perunan taudinaiheuttajista. Kasvustot voidaan suojata tehokkaasti PVY-tartunnalta vain käyttämällä PVY:ta kestäviä lajikkeita, sillä PVY:n leviäminen kirvojen välityksellä tapahtuu nopeasti ja tehokkaasti eikä sitä pystytä estämään kirvoja torjumalla. Virusgeenejä on siirretty kasveihin viruskestävyyden tuottamiseksi hieman yli kymmenen vuoden ajan. Myös PVY:ta kestäviä perunalajikkeita on tuotettu tällä tavoin käyttämällä PVY:n kuoriproteiinia, replikaasia, proteinaasia ja P1-proteiinia tuottavia geenejä. Kestävyys voi ilmetä täydellisenä kestävyytenä tartuntaa vastaan, vähäisenä viruspitoisuutena ja oireettomuutena tai oireiden hitaampana kehittymisenä.

Kestävyyden ilmeneminen ei useimmissa tapauksissa edellytä virusproteiinin tuottamista siirtogeenisessä kasvissa. Siirtogeenin lähetti-RNA:n tuottaminen riittää, sillä se käynnistää lähetti-RNA:han tarkoin kohdistuvan hajotusmekanismin, nk. transkription jälkeisen geeninhiljentämisen (post-transcriptional gene silencing). Tämä mekanismi tunnistaa ja hajottaa myös viruksen, jonka perintöaines on RNA:ta ja jossa on siirtogeeniä vastaava geenialue. Ilmeisesti kasvien luonnolliset kestävyysgeenit, jotka tunnista- vat viruksia, aiheuttavat samanlaisen mekanismin käynnistymisen, mikä johtaa kasvin toipumiseen virustartunnasta. Toisaalta viruksilla on havaittu olevan kyky estää geeninhiljentämiseen perustuvan kestävyysmekanismin toiminta.

Vaihtokuorisuus, siirtogeenin lähetti-RNA:n osien siirtyminen viruksen perintöainekseen (rekombinaatio), sekä siirtogeenin tuottaman virusproteiinin kyky lisätä kasvia tartuttavan viruksen leviämistä kasvissa tai oireiden ankaruutta (synergia), ovat mahdollisia riskejä, jotka liittyvät virusgeenien käyttöön siirtogeenisissä kasveissa. Näitä riskejä voidaan vähentää käyttämällä siirtogeenejä, jotka eivät tuota proteiinia tai joista on poistettu proteiinin toiminnan kannalta tärkeät osat.

Sekä patogeenivälitteiseen että luonnolliseen viruskestävyyteen liittyvän geeninhiljentämisen mekanismeja ei vielä täysin tunneta. Näiden mekanismien tutkiminen avaa uudenlaisia mahdollisuuksia kasvivirusten torjumiseksi. Tulevaisuudessa on myös mahdollista siirtää perunasta eristettyjä, luonnollisia PVY-kestävyysgeenejä virukselle alttiisiin lajikkeisiin. Luonnollisten kestävyysgeenien käyttö yhdessä erilaisten geeniteknisten taudinkestävyyssovellusten kanssa saattaisi olla tehokkain keino kasvien suojaamiseksi virustartunnoilta. 
